\title{
CLINICAL RESEARCH
}

\section{Guided transtracheal distal pulmonary brushing-washing: diagnosing acute pneumonia in high-risk patients}

\author{
P PELTIER, M MARTIN, J BARRIER, P GERMAUD, J Y LEBERRE, J Y GROLLEAU
}

\begin{abstract}
Transtracheal brushing-washing of distal pulmonary lesions was performed in 20 patients. Specimens were obtained by brushing and washing through a catheter placed in the pulmonary lesion with the aid of a guide. In nine patients pathogenic organisms were isolated. In the other 11 patients infectious studies of the specimens were negative, five of the patients (true-negatives) showing no infection and six (false-negatives) showing infection. Serious complications were uncommon, but one patient, who had diffuse intravascular coagulation, died.
\end{abstract}

This procedure seems to represent an advance over transtracheal aspiration and is an effective alternative to such invasive methods as transthoracic lung aspiration and pulmonary biopsy.

\section{Introduction}

Severe pulmonary infection in compromised patients demands prompt treatment with suitable antimicrobial drugs. Only three techniques of pulmonary investigation are reliable: directneedle transthoracic aspiration of the lung, pulmonary biopsy by thoracoscopy or thoracotomy, and transtracheal aspiration. Transtracheal aspiration has less risk of complications than the other methods and provides satisfactory results, ${ }^{1-4}$ but it is of little value when the infection is limited to the periphery of the

\footnotetext{
Service de Médecine Interne II, Hôpital Saint-Jacques, CHƯ 44035, Nantes, France

P PELTIER, MD, assistant chef de clinique

$M$ MARTIN, MD, assistant chef de clinique

J BARRIER, MD, assistant chef de clinique

P GERMAUD, MD, interne des hôpitaux

J Y GROLLEAU, MD, Professeur agrégé
}

Laboratoire de Bactériologie B, Hôpital Saint-Jacques, CHU 44035, Nantes, France

J Y LEBERRE, MD, assistant des hôpitaux lung and bacteria have not migrated to the trachea. ${ }^{5}$ We therefore decided to supplement transtracheal aspiration with guided brushing and washing of the distal pulmonary lesion as described by Aisner et al. ${ }^{6}$ We report here the results of a preliminary study in 20 patients.

\section{Patients and methods}

The procedure was carried out in 20 patients ( 9 men and 11 women) with acute pneumonia aged 27 to 83 years (mean 63 years). Nine had acute haematological diseases, which were characterised by aplasia or by an increase in very immature haematopoietic (blast) cells in the bone marrow, five were receiving immunosuppressive treatment, and six had severe metabolic or organic disorders (see table I). Six of the nine patients with acute haematological diseases had neutropenia (neutrophils $\left.<1 \times 10^{9} / 1\right)$. Haemostasis was normal in 11 patients and abnormal in nine; of the nine eight had thrombocytopenia with platelet counts of 17 to $50 \times 10^{9} / 1$ (mean $36 \times 10^{9} / 1$ ) and one diffuse intravascular coagulation. Studies of arterial blood gas pressures showed that $\mathrm{PaO}_{2}$ ranged from 4.0 to $11.7 \mathrm{kPa}(30$ to $88 \mathrm{~mm} \mathrm{Hg}$ ) (mean $8.7 \mathrm{kPa}(65 \mathrm{~mm} \mathrm{Hg})$ ) and $\mathrm{PaCO}_{2}$ ranged from 3.1 to $5.6 \mathrm{kPa}$ (23 to $42 \mathrm{~mm} \mathrm{Hg}$ ) (mean $4.3 \mathrm{kPa}(32 \mathrm{~mm} \mathrm{Hg})$ ).

A $2 \%$ solution of lidocaine was injected into the trachea, and percutaneous transtracheal puncture was performed in surgically sterile conditions, through the cricothyroid membrane in 10 cases and just below the cricoid cartilage in the other 10. Patients were placed in supine position, with a pillow beneath the shoulders to hyperextend the neck. Once a needle had been inserted in the trachea and directed caudad a catheter (Endoflex 15-13-20, $30 \mathrm{~cm} \times 2 \mathrm{~mm}, 6 \mathrm{~F}$ ) was rapidly threaded through the needle and introduced into the trachea. The needle was immediately withdrawn, leaving the catheter in place in the trachea. A guide (Surgimed A/S TJ $7121+24 \mathrm{D}, 120 \mathrm{~cm}$ ) was then threaded through the catheter. The use of guides with different degrees of curvature permitted bronchial catheterisation under fluoroscopic control. The guide was withdrawn once the catheter was placed in the site of the pulmonary lesion, and a brush (Meditech BT 10/58/140) was then threaded through the catheter and brushing performed under fluoroscopic control. The brush was withdrawn and placed in a sterile tube containing $1 \mathrm{ml}$ of sterile $0.9 \%$ sodium chloride solution for bacteriological studies. Washing was then performed with $20 \mathrm{ml}$ of sterile $0.9 \%$ sodium chloride solution, which was then collected for bacteriological, parasitological, virological, and cytological studies.

Bacteriological studies-Specimens were taken to the laboratory for 
processing within 10 minutes of collection. After Gram-and methyleneblue staining, the specimens were examined by direct microscopy to facilitate the initial choice of antibiotics before bacteriological identification. The medium for aerobes included blood and chocolate agar plates for incubation in $10 \% \mathrm{CO}_{2}$. For anaerobes the usual medium was Schaedler broth. Organisms arbitrarily considered as potential pathogens were ${ }^{5}$ : Streptococcus pneumoniae, Klebsiella pneumoniae, Haemophilus influenzae, Staphylococcus aureus, Enterobacteriaceae, Streptococcus pyogenes, Pseudomonas sp, Neisseria meningitidis, Bacteroides sp, fusobacteria, peptococci, peptostreptococci, clostridia, actinomyces, and mycobacteria. The specimens were considered positive if an intracellular organism with neutrophils was present on the Gram-stained smears and if potential pathogens were present on the culture alone.

Virological studies-Specimens were stored immediately in Hank's bovine $5 \%$ serum albumin, with penicillin, streptomycin, gentamicin, and colistin at a final concentration of $100 \mathrm{U} / \mathrm{ml}$ and with amphotericin B at a final concentration of $5 \mu \mathrm{g} / \mathrm{ml}$. Specimens were transported to the laboratory for processing within an hour of collection Each specimen was inoculated into three types of cell cultures: kidney primary cells from Vervet monkeys, human diploid cell lines $\left(\mathrm{MRC}_{5}\right)$, and continuous cell lines $\left(\mathrm{Hep}_{2}\right)$. Cells were observed for two weeks. The supernatants of negative cultures were inoculated into similar new cultures.

Mycoplasma pneumoniae culture-For isolating Mycoplasma pneumoniae we used transport and media derived from Hay-Flick's medium incubated in $5 \% \mathrm{CO}_{2}$ at $37^{\circ} \mathrm{C} .{ }^{7}$ Agar plates were examined twice a week for three weeks and broth medium every day for three weeks.

Parasitological studies-Specimens were transported to the laboratory for processing within an hour of collection. A microscopic examination was performed, the cultures being made on Sabouraud medium: two tubes at $2 \%$, two tubes at $2 \%$ with chloramphenicol added, one tube of each being incubated at $22^{\circ} \mathrm{C}$ and the other at $37^{\circ} \mathrm{C}$.

Cytological studies-After cytocentrifugation and Giemsa staining microscopic examination was performed.

\section{Results}

The patients generally tolerated the procedure well. A few patients suffered paroxysms of coughing, but an injection of $1 \mathrm{ml}$ of lidocaine $(2 \%)$, repeated if necessary, controlled the cough and allowed catheterisation to continue. The examination lasted longer (mean 25 minutes) in the first patients investigated than in the later ones (10 minutes after transtracheal puncture).
In nine cases a pathogenic organism was isolated (table I); in one of these patients (case 10) the presence of $H$ parainfluenzae intracellularly on a Gram-stain smear indicated that the specimen was positive. In eight patients rapid antimicrobial treatment to combat the particular pathogen led to improvement of the pneumonia. The remaining patient (case 9) died before treatment could be started.

In five of the other 11 patients examination of the brushing-washing specimens for an infecting organism or virus proved negative. One patient (case 3) had hyperosmolar diabetes with cardiac failure. Another (case 14) probably had pulmonary leukaemic cell localisation because leukaemic cells were recognised on cytological examination of the washing fluid. A third patient (case 7) had acute lymphoblastic leukaemia resistant to antimitotic chemotherapy; the pulmonary infiltrates and fever persisted for several weeks despite the use of different antimicrobial drugs, and this patient was considered to have pulmonary leukaemic cell localisation. A pulmonary lesion characteristic of Hodgkin's disease was verified by open-lung biopsy in case 8 , and in case 13 the pulmonary lesion suggested cancer of the bronchus. Biopsy had shown a cancer of the larynx in this patient, and the lesion in the bronchus, as viewed by fibreoptic bronchoscopy, suggested a cancer. The histological study of the biopsy specimen from the bronchus showed squamous metaplasia, and pulmonary infiltrates persisted despite the use of several antibiotics.

In the six remaining patients the pneumonia was considered infectious. In two patients pulmonary infiltrates disappeared without the use of antibiotics: in case 1 herpes virus serodiagnosis was positive, as was varicella serodiagnosis in case 6 . In three patients (cases 5, 19, and 20) pulmonary infiltrates disappeared with antibiotic treatment. In case 12 tuberculosis chemotherapy improved the pneumonia, and pericardiac puncture permitted isolation of $M$ tuberculosis on culture. Specimens from sputum, pulmonary washing fluid, and urine were negative.

In three patients (cases 13,17, and 20) antibiotics (benzylpenicillin ampicillin-amikacin, and ampicillin) had been administered less than four days before the procedure. In case 17 (ampicillin) pulmonary brushing-washing showed a pathogen (Klebsiella pneumoniae) that was resistant to ampicillin.

The results of the procedure differed according to the type of pulmonary infiltrate shown on the chest radiograph (table II). More specimens were positive when the radiograph showed alveolar filling than when it showed interstitial pneumonitis. When the pattern or alveolar filling was local the findings were more reliable than for diffuse lesions. When the radiographs showed interstitial pneumonitis, specimens were less reliable for local lesions than for diffuse lesions.

Complications-In 10 patients the trachea was entered just below the cricoid cartilage. In four of these patients the slight haemoptysis

TABLE I-Details of the 20 patients examined

\begin{tabular}{|c|c|c|c|c|c|c|}
\hline $\begin{array}{l}\text { Case } \\
\text { No }\end{array}$ & Condition & $\underset{\left(\text { platelets } \times 10^{9} / 1\right)}{\text { Haemostasis }}$ & Organisms & Chest radiograph & $\begin{array}{l}\text { Findings on other } \\
\text { studies }\end{array}$ & Diagnosis \\
\hline 1 & ALL & Normal & 0 & Diffuse interstitial pneumonitis & Herpes virus $>0$ & Herpes virus infection \\
\hline $\begin{array}{l}2 \\
3\end{array}$ & $\begin{array}{l}\text { Hypothyroidism } \\
\text { Micromegakaryocytic } \\
\text { leukaemia }\end{array}$ & $\begin{array}{l}\text { Normal } \\
32\end{array}$ & $\begin{array}{l}\text { Staph aureus } \\
0\end{array}$ & $\begin{array}{l}\text { Local alveolar filling } \\
\text { Local interstitial pneumonitis }\end{array}$ & $\begin{array}{l}0 \\
0\end{array}$ & $\begin{array}{l}\text { Staph aureus infection } \\
\text { Hyperosmolar diabetes with } \\
\text { cardiac failure }\end{array}$ \\
\hline 4 & $\begin{array}{l}\text { Chronic lymphocytic } \\
\text { leukaemia }\end{array}$ & Normal & Pasteurella multocida & Diffuse interstitial pneumonitis & 0 & $P$ multocida infection \\
\hline 5 & $\mathrm{AML}$ & 50 & 0 & Diffuse alveolar filling & 0 & Infection ? Improvement \\
\hline 6 & $\begin{array}{l}\text { Systemic lupus } \\
\text { erythematosus }\end{array}$ & Normal & 0 & Diffuse interstitial pneumonitis & $\begin{array}{l}\text { Varicella }>0 \\
\quad \text { (serodiagnosis) }\end{array}$ & Varicella \\
\hline 7 & Acute monoblastic & 30 & 0 & Local alveolar filling & thende & Leukaemic localisation \\
\hline 8 & Hodgkin's disease & Normal & 0 & Local alveolar filling & $\begin{array}{l}\text { Hodgkin's disease } \\
\text { (pulmonary biopsy) }\end{array}$ & Hodgkin's localisation \\
\hline 9 & Coma & $\begin{array}{l}\text { Diffuse intravascular } \\
\text { coagulation }\end{array}$ & Proteus & Diffuse alveolar filling & 0 & Proteus infection \\
\hline 10 & Cirrhosis and mitral & Normal & Hparainfluenzae & Local alveolar filling & 0 & Hparainfluenzae infection \\
\hline $\begin{array}{l}11 \\
12\end{array}$ & $\begin{array}{l}\text { Myeloma } \\
\text { Diabetes pericarditis }\end{array}$ & $\begin{array}{l}\text { Normal } \\
\text { Normal }\end{array}$ & ${ }_{0}^{K l o z a e n a e}$ & $\begin{array}{l}\text { Local alveolar filling } \\
\text { Local interstitial pneumonitis }\end{array}$ & $\begin{array}{l}0 \\
M \text { tuberculosis } \\
\text { (pericardiac puncture) }\end{array}$ & $\begin{array}{l}\text { Klozaenae infection } \\
\text { Tuberculosis }\end{array}$ \\
\hline 13 & AML & 49 & 0 & Local alveolar filling & $\begin{array}{l}\text { Squamous metaplasia } \\
\text { (bronchus biopsy) }\end{array}$ & Cancer of the bronchus \\
\hline 14 & $\begin{array}{l}\text { Acute monoblastic } \\
\text { leukaemia }\end{array}$ & 50 & 0 & Diffuse interstitial pneumonitis & $\begin{array}{l}\text { Monoblasts } \\
\text { (washing fluid) }\end{array}$ & Leukaemic localisation \\
\hline 15 & $\mathrm{AML}$ & 17 & Candida albicans & Diffuse alveolar filling & $\begin{array}{l}C \text { albicans }>0 \\
\text { (serodiagnosis) }\end{array}$ & C albicans infection \\
\hline 16 & $\begin{array}{l}\text { Diffuse pulmonary } \\
\text { fibrosis }\end{array}$ & Normal & Str pneumoniae & Diffuse alveolar filling & 0 & Str pneumoniae infection \\
\hline $\begin{array}{l}17 \\
18 \\
19\end{array}$ & $\begin{array}{l}\text { Haemochromatosis } \\
\text { Pre-leukaemia } \\
\text { Pancreatitis }\end{array}$ & $\begin{array}{l}\text { Normal } \\
30 \\
\text { Normal }\end{array}$ & $\begin{array}{l}\text { Kl pneumoniae } \\
\text { Staph aureus } \\
0\end{array}$ & $\begin{array}{l}\text { Local alveolar filling } \\
\text { Local alveolar filling } \\
\text { Local interstitial pneumonitis }\end{array}$ & $\begin{array}{l}0 \\
0 \\
0\end{array}$ & $\begin{array}{l}\text { Kl pneumoniae infection } \\
\text { Staph aureus infection } \\
\text { Infection, improved with } \\
\text { vancomycin }\end{array}$ \\
\hline 20 & AML & 30 & 0 & Local interstitial pneumonitis & 0 & $\begin{array}{l}\text { Infection, improved with } \\
\text { penicillin-amikacin }\end{array}$ \\
\hline
\end{tabular}


TABLE II-Results of the procedure according to features shown on the chest radiograph

\begin{tabular}{llllllc}
\hline \multicolumn{2}{c}{ Chest radiograph } & & & Positive & $\begin{array}{c}\text { True- } \\
\text { negatives }\end{array}$ & $\begin{array}{c}\text { False- } \\
\text { negatives }\end{array}$ \\
\hline $\begin{array}{l}\text { Local alveolar filling } \\
\text { Diffuse alveolar filling } \cdots\end{array}$ & $\cdots$ & $\cdots$ & $\cdots$ & 5 & 3 & 0 \\
Local interstitial pneumonitis & $\cdots$ & $\cdots$ & $\cdots$ & 3 & 0 & 1 \\
Diffuse interstitial pneumonitis & $\cdots$ & $\cdots$ & 1 & 1 & 2 \\
\hline
\end{tabular}

that occurred persisted for two hours. One patient suffered mild subcutaneous emphysema with no complications. One patient (case 9) died after a tracheal haemorrhage. This patient had diffuse intravascular coagulation, which would theoretically have contraindicated the tracheal puncture performed; puncture was performed, however, because of his worsening neurological symptoms and the spread of pneumonia despite the use of several antibiotics. Of the 10 other patients, in whom the puncture was performed through the cricothyroid membrane, six developed mild subcutaneous emphysema (on the front of the neck in one case). There were no instances of haemorrhage, infection of the puncture site, or respiratory distress syndrome.

\section{Discussion}

All virological and $M$ pneumoniae studies were negative. The procedure yielded a pathogenic organism in nine cases and nonpathogenic bacteria or fungi in 11 (five true-negatives, six falsenegatives). The overall sensitivity of the technique was $60 \%$ and the specificity $100 \%$. These values may be questioned, however, because there were no other bacteriological (all blood cultures were negative) or histological criteria to assess the infectious origin of the pneumonia. When a chest radiograph showed alveolar filling sensitivity and specificity were fairly high, especially in cases of local lesions. Serious complications were rare with this technique; and the transtracheal puncture that led to the death of one patient would not have been performed if his condition had not been so critical.

Making the puncture through the cricothyroid membrane rather than below the cricoid cartilage reduces the risk of haemorrhage. Thrombocytopenia and hypoxia do not contraindicate transtracheal puncture if it is preceded by platelet transfusion and if oxygen is given before, during, and after the procedure. The clinician must, however, reckon with the possibility of serious complications, including deaths. ${ }^{8} 9$

Several workers have noted that cultures of expectorated sputum do not accurately indicate the bacteriology of the distal respiratory tract. ${ }^{1011}$ The main problem appears to be contamination of the specimen by oral flora during passage through the upper airways. For similar reasons specimens obtained by aspiration during fibreoptic bronchoscopy also pose problems of interpretation..$^{12-14}$ Two recent studies, ${ }^{15} 16$ however, have shown the specificity of a technique using a catheter with telescoping cannulas sealed at the distal end with polyethyleneglycol plugs. This technique was tested with fibreoptic bronchoscopy on 24 patients. Transtracheal puncture shunting of the laryngeal and pharyngeal regions has also been shown to permit aspiration of secretions uncontaminated by oral flora and which are, theoretically, representative of the distal infection..$^{1-4}$ Bacteriological studies in our department have, however, consistently proved negative when there are no bronchial secretions, ${ }^{17}$ a factor which lends support to the use of guided transtracheal brushing-washing of distal lesions as shown in this study. Direct-needle transthoracic aspiration of the lung and pulmonary biopsy are good methods for recovering potential pathogens, ${ }^{18-20}$ but complications, including haemoptysis, pulmonary haemorrhage, pneumothorax, and death, ${ }^{21-24}$ are common. Moreover, these techniques are contraindicated when patients have haemostatic disorders or have to undergo positivepressure ventilation.

If further studies confirm our preliminary results guided transtracheal brushing-washing of distal pulmonary lesions should be considered an effective alternative to more invasive methods such as transthoracic lung aspiration and pulmonary biopsy. This technique should be performed in high-risk cases of acute pneumonia when there are no bronchial secretions, and especially when the chest radiograph shows alveolar filling.

\section{References}

${ }^{1}$ Bartlett JG, Rosenblatt JE, Finegold SM. Percutaneous transtracheal aspiration in the diagnosis of anaerobic pulmonary infection. Ann Int Med 1973;79:535-40.

${ }^{2} \mathrm{Hahn} \mathrm{HH}$, Beaty HN. Transtracheal aspiration in the evaluation of patients with pneumonia. Ann Int Med 1970;72:183-7.

${ }^{3}$ Kalinsky RW, Parker RH, Brandt E, Hoeprich PD. Diagnostic usefulness and safety of transtracheal aspiration. N Engl f Med 1967;276:604.

${ }^{4}$ Pratter MF, Irwin RS. Transtracheal aspiration: guidelines of safety. Chest $1979 ; 76: 518-20$.

${ }^{5}$ Bartlett JG. Diagnostic accuracy of transtracheal aspiration. Bacteriologic studies. Am Rev Resp Dis 1977;115:777-82.

${ }^{6}$ Aisner J, Kvols LK, Sickles EA, Schimpff SC, Wiernik PH. Transtracheal selective bronchial brushing for pulmonary infiltrates in patients with cancer. Chest 1976;69:367-71.

${ }^{7}$ Hayflick L, Chanock RM. Mycoplasma species of man. Bacteriol Rev $1965 ; 29: 186$.

${ }^{8}$ Spencer DC, Beaty HN. Complication of transtracheal aspiration. N Engl 7 Med $1972 ; 286: 304$.

9 Unger KM, Moser KM. Fatal complication of transtracheal aspiration. Arch Int Med 1973;132:437.

${ }^{10}$ Bartlett JG, Finegold SM. Bacteriology of expectorated sputum with quantitative culture and wash technique compared to transtracheal aspirates. Am Rev Resp Dis 1978;117:1019-27.

11 Davidson M, Tempest B, Palmer D. Bacteriologic diagnosis of acute pneumonia comparison of sputum, transtracheal aspirates and lung aspirates. F $A M A 1976 ; 235: 158-63$.

12 Bartlett JG, Alexander J, Mayhew J, Sullivan-Sigler N, Gorbach SL. Should fibreoptic bronchoscopy aspirates be cultured? Am Rev Resp Dis 1976;114:73-8.

${ }^{13}$ Conte BA, Laforet EG. The role of the topical anesthetic agent in modifying bacteriologic data, obtained by bronchoscopy. N Englf $\mathrm{Med} 1962$ 267:957.

${ }^{14}$ Erlich $\mathrm{H}$. Bacteriologic studies and effects of anesthetic solutions on bronchial secretions during bronchoscopy. Am Rev Resp Dis 1961 ;84: 414.

${ }^{15}$ Hayes DA, McCarthy LC, Friedman M. Evaluation of two broncho fibreoptic methods of culturing the lower respiratory tract. Am Rev Resp Dis $1980 ; 122: 319-23$.

${ }^{16}$ Wimberley N, Faling LJ, Bartlett JG. A fibreoptic bronchoscopy technique to obtain uncontaminated lower airway secretions for bacterial culture. Am Rev Resp Dis 1979;119:337-43.

17 Peltier P, Martin M, Barrier J, Leberre JY, Grolleau JY. Intérêt diagnostique de la ponction transtrachéale dans le diagnostic des pneumopathies survenant au cours d'hémopathie. Med et Mal Inf (in press).

18 Andersen HA, Fontana RS. Transbronchial lung. Biopsy for pulmonary diseases: technique and results in 450 cases. Chest $1972 ; 62: 125-8$.

${ }^{19}$ Chaudhary S, Hughes WT, Keldman J. Percutaneous transthoracic needle aspiration of the lung: diagnosing Pneumocystis carinii pneumonitis. Am $\mathcal{F}$ Dis Child 1977;131:902-7.

${ }^{20}$ Zavala DC, Schoell JE. Ultrathin needle aspiration of the lung in infectious and malignant disease. Am Rev Resp Dis 1981;123:125-31.

21 Ballantine TVN, Grosfeld JL, Knapek RM. Interstitial pneumonitis in the immunologically suppressed child: an urgent surgical condition. f Pediat Surg 1977;12:501-8.

22 Fontana RS, Miller WE, Beabout JW. Transthoracic needle aspiration of discrete pulmonary lesions. Experience in 100 cases. Med Clin North America 1970;54:961-71.

${ }^{23}$ Poe RM, Utell MJ, Israel RH, Hall WJ, Eshleman JD. Sensitivity and specificity of the non specific transbronchial lung biopsy. Am Rev Resp Dis $1979 ; 119: 25-31$.

${ }^{24}$ Stringer RS, Stiles QR, Lindesmith GC. Use of lung biopsy in diagnosis of pulmonary lesions in children. Am Surg 1968;34:810-12.

(Accepted 28 August 1981)

ONE HUNDRED YEARS AGO The following is an extract from a letter from a medical officer in one of the lunatic asylums in the west of Ireland. The writer says: "It is to be hoped that something will at last be done to restore order in the country. I have had two men admitted here lately who have been driven out of their minds by fear of assassination: one of them, from near this, whose house was fired into because his sons worked for $\mathrm{Mr}$ _ is the son of the old man — who was shot while sitting at his son's fireside." (British Medical fournal, 1882.) 